\title{
Peran Guru dalam Memotivasi Siswa Mengikuti Pembelajaran Daring di SMP Negeri 2 Belimbing
}

\author{
Melinda Anggia Sari ${ }^{1}$, Ramtia Darma Putri ${ }^{2}$ Arizona $^{3}$ \\ Universitas PGRI Palembang ${ }^{1}$ \\ Email: melindaanggia25@gmail.com \\ Universitas PGRI Palembang ${ }^{2}$ \\ Email: tyadhuarrma27@gmail.com \\ Universitas PGRI Palembang ${ }^{3}$ \\ Email: arizona.karno@gmail.com
}

\begin{abstract}
ABSTRAK
Guru sebagai tenaga pendidikan memiliki peran, fungsi dan tanggung jawab yang senatiasa diemban dalam setiap aktivitasnya sebagai pendidik. Tujuan penelitian ini adalah untuk mengetahaui peran guru dalam memotivasi belajar siswa pada SMP Negeri 2 Belimbing. Jenis penelitian yang digunakan adalah kualitatif penelitian yang berlandaskan pada filsafat positivisme, digunakan untuk meneliti pada kondisi obyek yang alamiah, dimana peneliti adalah sebagai instrumen kunci. Sampel pada penelitian ini adalah Guru Bimbingan Konseling dan Wali kelas sebagai guru bidang studi tertentu yang mendapatkan tugas tambahan sebagai penanggung jawab dinamika pembelajaran di dalam kelas tertentu dimana Teknik pengumpulan data menggunakan observasi dan wawancara. Penelitian ini berfokus pada peran guru secara umum adalah sebagai tugas pendidikan meliputi mendidik, mengajar, dan melatih. Dan seseorang guru juga berperan untuk membantu siswa dalam mengembagkan keterampilan serta pengetahuan siswa. Oleh karena itu, guru harus bias membuat siswanta tertarik untuk mengikuti pelajaran, dalam memotivasi siswa mengikuti pembelajaran daring di SMP Negeri 2 Belimbing. Guru memiliki peran sebagai motivator bagi peserta didiknya. Peran motivator sangat dibutuhkan oleh siswa karena motivasi yang baik dari guru akan dapat mendorong kamauan siswa siswa untuk meningkatkan proses dan hasil belajar siswa. Guru juga mengetahui kondisi peserta didik yang diajarnya karena bila guru mengetahui kondisi peserta didik yang diajarnya maka proses pembelajaran akan berjalan kondusif. Dari hasil wawancara juga didapatkan bahwa terlihat dari cara guru memacu motivasi belajar siswa. Pada saat pembelajaran daring guru selalu memberikan motivasi dan semangat belajar siswa melalui chat yang memungkinkan siswa untuk selalu semangat untuk belajar pada pembelajaran daring.
\end{abstract}

Kata Kunci: Peran Guru, Motivasi Siswa, Pembelajaran Daring 


\title{
The Role Of The Teacher In Motivating Students To Follow Online Learning At Smp Negeri 2 Belimbing
}

\begin{abstract}
Teachers as education personnel have roles, functions and responsibilities that are always carried out in each of their activities as educators. The purpose of this study was to determine the role of the teacher in motivating student learning at SMP Negeri 2 Belimbing. The type of research used is qualitative research based on the philosophy of positivism, used to examine the condition of natural objects, where the researcher is the key instrument. responsible for dynamics in certain classes where data collection techniques use observation and interviews. This study focuses on the role of the teacher in general as an educational task including educating, teaching, and training. And a teacher is also knowledge to help students in developing skills as well as students. Therefore, teachers must be able to make students interested in taking lessons, in motivating students to take bold lessons at SMP Negeri 2 Belimbing. Teachers have a role as a motivator for their students. The role of motivator is needed by students because good motivation from the teacher will encourage students to improve the process and student learning outcomes. The teacher also knows the condition of the students he teaches because if the teacher knows the condition of the students he teaches, the learning process will be conducive. From the results of the interview, it was also found that it was seen from the way the teacher stimulated student learning motivation. During online learning, the teacher always provides motivation and enthusiasm for student learning through chat which supports students to always be enthusiastic about learning in bold learning.
\end{abstract}

\section{Keywords: Teacher's Role, Student Motivation, Online Learning}

\section{PENDAHULUAN}

Guru sebagai tenaga pendidikan memiliki peran, fungsi dan tanggung jawab yang senatiasa diemban dalam setiap aktivitasnya sebagai pendidik. Guru harus memiliki emosional yang stabil, kejujuran yang tinggi serta memiliki pengetahuan yang luas dan harus menguasai teori/praktik pendidikan, mengerti dan menguasai kurikulum serta metode pendidikan. Selain itu, guru harus mampu bersikap objektif dan professional ketika mengadapi seluruh siswanya di sekolah tanpa terkecuali. Guru bersikap objektif agar dapat mengembakan seluruh potensi yang dimiliki oleh semua siswa baik itu siswa yang cerdas atau yang malas, dan bersikap profesional tanpa peduli siswa itu berasal dari keluarga kaya/miskin.

Peran guru bimbingan dan konseling di dalam sekolah dapat membantu tugas bersama pendidikan dalam mencapai amanat pendidikan nasional. 
Berbagai fenomena yang ditimbulkan oleh siswa seperti tawuran, penyalahgunaan obat-obatan terlarang, perilaku seksual yang menyimpang, dekradasi moral, perstasi belajar yang tidak memuaskan, masalah keluarga, kurangnya motivasi belajar, bahkan gagal Ujian Akhir Nasional. Berbagai fenomena sosial yang timbul ini memerlukan penanganan khusus oleh guru bimbingan dan konseling melalui pelaksanaan layanan bimbingan dan konseling di sekolah. Salah satu peran guru bimbingan dan konseling di sekolah ialah melaksanankan layanan, pelaksanaan yang sesuai ini agar siswa dapat mandiri.

Menurut Hurlock dalam (Haerunisa dkk, 2015: 27) kebutuhan dasar anak meliputi : 1) Kebutuhan fisik dapat dipenuhi apabila anak mengkonsumsi makanan yang sesuai dengan kebutuhan umumnya, pemantauan tumbuh kembang, pemeriksaan kesehatan, pengobatan, reabilitasi, imunisasi, pakaian, pemukiman yang sehat dan lain-lain, 2) Kebutuhan emosi meliputi segala bentuk hubungan yang erat, hangat dan menimbulkan rasa amanah serta percaya diri sebagai dasar bagi perkembangan selanjutnya, 3) Kebutuhan stimulasi atau pendidikan meliputi segala aktivitas yang dilakukan mempengaruhi proses berfikir, berbahasa, bersosialisasi, dan kemandirian seorang anak.

Kegiatan pembelajaran di sekolah yang diberikan oleh guru BK/ konselor bersama guru mata pelajaran yaitu menghadapi siswa dengan beraneka ragam karakteristik yang dimilikinya. Salah satu masalah yang sering dihadapi oleh para siswa adalah rendahnya hasil belajar yang mereka capai. Padahal hasil belajar akan menentukan kesuksesan belajar, kelulusan dan kelanjutan studi siswa.

Menurut Jahja (2011: 356) motivasi merupakan suatu tindakan atau kondisi yang timbul dari dalam diri seseorang, dengan begitu motivasi dapat memberikan inspirasi agar seseorang mau melaukan kegiatan. Motivasi belajar adalah keseluruhan daya penggerak baik dari dalam diri maupun dari luar siswa dengan menciptakan serangkaian usaha untuk menyediakan kondiskondisi tertentu) yang menjamian kelangsungan dan memberikan arah pada kegiatan belajar, sehingga tujuan yang dikehendaki oleh subjek belajar itu pada tercapai. Berdasarkan pengertian tersebut dapat dikatakan bahwa motivasi merupakan sebuah motor yang mampu menjadi penggerak dan meggerakkan seseorang untuk melakukan sesuatu atau kegiatan yang mengarah pada tercapainya suatu tujuan 
yang di kehendaki. Dengan demikian motivasi merupakan hal yang penting yang harus dimiliki oleh setiap orang dalam rangka mencapai tujuan yang telah ditetapkan.

Kegiatan belajar mengajar, motivasi belajar merupakan dorongan yang timbul baik dari dalam maupun dari luar diri siswa, yang mampu menumbulkan semangat dan kegairahan belajar serta memberikan arah pada kegiatan belajar sehingga tujuan yang dikehendaki dapat tercapai.

1. Motivasi Interistik adalah yang di tibulkan dari diri seseorang.motivasi ini biasanya timbul karena adanya harapan, tujuan dan keinginan seseorang terhadap sesuatu sehingga dia memiliki semangat untuk mencapai itu.

2. Motivasi ekstrinsik adalah Sesutu yang di harapkan akan di peroleh dari luar diri seseorang. Motivasi ini biasanya dalam bentuk nilai dari suatu materi, misalanya imbalan dalam bentuk uang atau intensif lainya yang diperoleh atas suatu upaya yang telah di lakukan.

Berdasarkan observasi yang peneliti lakukan. Bimbingan konseling merupakan upaya guru untuk membantu siswa dalam menghadapi permasalahan yang terjadi pada siswa 1, mengabaikan PR yang diberikan guru 2. Kurang memhami pembelajaran yang di berikan guru. 3. Merasa terasing dalam aktivitas kelompok. 4. kesulitan dalam menghadapi situasi lingkungan social yang baru. Bimbingan konseling di sekolah sangat dibutuhakan untuk membantu permasalahan di sekolah dan lingkungannya. Bimbingan konseling merupakan salah satu segi pendidikan mempunyai peranan penting dalam upaya mencapai tujuan pendidikan. Bimbingan dan konseling adalah pelayanan bantuan untuk peserta didik baik secara perorangan maupaun kelompok agar mandiri dan bisa berkembang secara optimal.

Dalam hal ini pembelajaran daring banyak sekali hambatan seperti pada jaringan internet, kurang aktifnya siswa dalam proses pembelajaran, hanya sebagian siswa yang mengikuti pembelajaran daring tepat pada jam pembelajaran ,siswa hanya memperhatikan penjelasan guru tanpa adanya interaksi antara guru dengan siswa sehingga kurangnya motivasi siswa untuk belajar. Selain itu ada juga siswa yang tidak memiliki Handphone (HP). Masalah ini mengakibatkan 
kurangnya minat belajar serta motivasi belajar siswa pada masa pembelajaran daring.

Berdasarkan informasi awal yang peneliti ketahui di SMP Negeri 2 Belimbing, pada peroses bembelajaran daring guru banyak menemukan hambatan dalamperoses pembelajaran terutama dalam memotivasi siswa untuk memeberikan semangat dan dorongan secara aktif kepada siswa di dalam kelas selama peroses belajar mengajar atau pembelajaran langsung. proses pembelajaran daring sulitnya akses internet mengurangi semangat siswa untuk belajar sehinga guru memiliki peran sangat penting untuk memotivasi siswa belajar pada masa pembelajaran daring.

\section{METODELOGI PENELITAN}

Metode Penelitian ini mengunakan metode penelitian kualitatif. Menurut Sugiyono, (2016: 15) metode penelitian kualitatif adalah metode penelitian yang berlandaskan pada filsafat positivisme, digunakan untuk meneliti pada kondisi obyek yang alamiah, dimana peneliti adalah sebagai instrumen kunci, pengembilan sampel sumber data dilakukan secara purposive Sampling adalah teknik pengambilan sampel sumber data dengan pertimbangan tertentu, misalnya orang tersebut di anggap paling tahu tentang apa yang kita harapkan. dan snowbaal,sampling adalah teknik pengambilan sampel bersumber data yang pada awalnya jumblahnya sedikit, lama- lama menjadi besar (Sugiyono, 2009:300)

Pengumpulan data yang di lakukan dalam penelitan ini adalah obvservasi, wawancara dan domukentasi.untuk memperoleh data primer adalah sumber data yang diperoleh langsung oleh peneliti dalam penelitian ini digunakan alat penggumpulan data berupa obvservasi dan wawancara. Sedangkan sumber data skunder adalah sumber data yang tidak diperoleh oleh langsung peneliti, biasanya sumber data ini di peroleh dari pihak lain. Dimana dalam penelitian ini dapat di bedakan menjadi dua yaitu data primer dan data skunder.

Berdasarkan pendapat (Sugiyono, 2013: 375) teknik pengumpulan data merupakan langakah yang paling utama dalam penelitian, karena tujuan utama dari penelitian adalah mendapatkan data.

Menurut Kartono dikutip dalam (Gunawan, 2013: 143) obvservasi ialah studi yang di sengaja tentang phenomena sosial dan gejala- gejala psikis dengan 
jalan pengamatan dan pencatatan. Jadi obvservasi merupakan teknik pengumpulan data yang dilakukan dengan cara mengadakan penelitian secara teliti terlebih dahulu dalam hal ini mengenai peran guru dalam memotivasi siswa mengikuti pembelajaran daring di SMP Negeri 2 Belimbing.

Wawancara merupakan salah satu metode pengumpulan data dalam penelitian kualitatif. Menurut (Gunawan, 2013: 162) wawancara merupakan suatu kegitan Tanya jawab dengan tatap muka (face to face) antar pewawancara (interviewer) dan yang di wawancari (interview) tentang masalah yang di teliti, di mana pewawancara bermaksud memperoleh persepsi, sikap dan pola pikir dari yang di wawancarai yang relevan dengan masalah yang di teliti.

Dokumentasi merupakan catatan peristiwa yang sudah berlalu. Dokumen bisa berbentuk tullisan, gambar, atau karya-karya monumental dari seseorang. Adapun dokumetasi dari penelitian ini yaitu dokumentasi selama kegiatan berlangsung.

Menurut (Sugiyono, 2016: 335) analisi data adalah proses mencari dan menyusun secara sistematis data yang di peroleh dari hasil wawan cara, catantan lapangan, dan dokumentasi dengan cara megoragnisasiakan data kedalam kategori, menjabarakan kedalam unit- unit, melakukan sisntesa, menyusun kedalam pola, memilih mana yang penting dan yang akan dipelajari, dan membuat kesimpulan sehinga mudah di pahami oleg diri sendiri maupaun orang lain.

\section{METODE PENELITIAN}

Berdasarkan data yang saya peroleh dari observasi dan wawancara dimana Peran seorang guru sangat penting karena dimulai dari tingkah laku guru yang dapat dijadikan dasar utama motivasi bagi siswa. Karena dengan kebiasaan baik, siswa akan mampu mengalami peningkata belajar. Siswa mampu mengikuti dan menerapkan tata cara kesopanan yang dicontohkan oleh seorang guru yang berperan sebagai motivator teladan. Selain itu juga dibutuhkan interaksi yang baik anatara guru dengan siswa agar dapat menciptakan suasana belajar yang diharapkan olehseorang guru yaitu suasana belajar yang aktif dan kondusif.

Berdasarkan hasil wawancara yang didapatkan dari guru BK di SMP negeri 2 Belimbing bahwa peran guru merupakan faktor yang sangaat penting dalam menciptakan kondisi pembelajaran yang efektif. Dari hasil wawancara yang 
didapatkan dari bapak A B S.Pd bawa cara memotivasi siswa belajar dalam pembelajaran daring yaitu dengan memaksimalkan fasilitas dan persiapan saat belajar mengajar dikelas. Setiap seminggu sekali guru berikan tugas. masingmasing siswa sudah dibagikan buku dan diberikan lembaran berupa penelitan soal yang akan di kerjakan siswa pada saat daring. Guru selalu menyemangati siswa walaupaun hanya melalui chat personal dan grup. Dan juga tegas jika ada perserta didik yang tidak displin. Malas ketika belajar di rumah.

Hasil wawancara didapatkan bahwa guru memiliki peran sebagai motivator bagi peserta didiknya. Peran motivator sangat dibutuhkan oleh siswa karena motivasi yang baik dari guru akan dapat mendorong kamauan siswa siswa untuk meningkatkan proses dan hasil belajar siswa. Guru juga mengetahui kondisi peserta didik yang diajarnya karena bila guru mengetahui kondisi peserta didik yang diajarnya maka proses pembelajaran akan berjalan kondusif. Dari hasil wawancara juga didapatkan bahwa terlihat dari cara guru memacu motivasi belajar siswa. Pada saat pembelajaran daring guru selalu memberikan motivasi dan semangat belajar siswa melalui chat yang memungkinkan siswa untuk selalu semangat untuk belajar pada pembelajaran daring. Pada saat pembelajaran tak lupa guru juga memberikan kesempatakan kesempatkan untuk siswa bertanya tentang materi pembelajaran sehingga memunculkan aktivitas timbal balik anatara guru dengan siswa, siswa satu dan siswa lainnya

Pada masa pembelajaran daring peran guru sangat besar dalam memotivasi siswa untuk tetap semangat belajar karena dalam pembelajaran daring banyak sekali kendala yang dihadapi oleh guru, dengan adany motivasi yang diberikan oleh guru maka akan membantu peserta didik untuk selalu bersemangat mengikuti pembelajaran. Selain menjadi motivator guru juga menjadi fasilitator bagi para siswanya.

Hasil wawancara yang didapatkan dari ibu E N S.Pd bahwa Kesulitan mengajar pada saat pembelajaran daring yaitu dalam pelaksanaan nya kondisi jaringan yang tidak stabil dan kesulitan pada perserta didik dalam memahami materi. Untuk kesulitan jaringan internet tidak stabil guru memeberi solusi untuk mencari tempat yang jaringannya bagus pada saat pembelajaran, untuk kesulitan siswa tidak memiliki kutoa guru mendata nomor whatsAPP agar bias 
mendapatkan kuota gratis dari permendikbud. untuk mengatasi siswa yang terlambat mengikuti pembelajaran yaitu mengirimkan ulang materi pemblajaran dan beri waktu.

\section{HASIL DAN PEMBAHASAN}

Hasil penelitian di SMP Negeri 2 Belimbing dapat di ketahui peran seorang guru BK dalam meningkatkan motivasi belajara siswa pada saat belajar daring sebagai guru harus memperhatikan siswa nya agar siswa tersebut bias belajar jauh lebih baik. Hal ini perlu dibuktikan dengan adanya sosok seorang guru maka dari itu seorang guru sangat di hormati oleh semua siswa dan kalang tersebut. Hal tersebut menjadikan seorang guru menjaga pola senantiasanya dia menjaga pola tingkah lakunya di lingkungan sekolah tersebut dan dilingkungan masyarakat. Dari hasil wawancara juga dapat disimpulkan bahwa seorang guru harus bisa mengetahui karakter seorang siswanya dan guru juga dapat memenuhi keinginan seorang perta didik dalam proses pelajaran. Sehingga dapat simpulkan adalah peran seorang guru dalam meningkatkan motivasi belajar siswa harus dimulai dengan menciptakan perasaan nyaman dan menyenangakan di dalam kelas. Sehigga siswa tidak merasakan bosan pada saat peroses belajar di dalam kelas maupun belajar dari online sehingga siswa dapat merasakan nyam dan tenangdi saat belajar di kelas.

Perasan nyaman dan menyenangkan yang muncul dalam peroses pembelajaran di kelas tentu mampu membuat siswa belama- lama untuk fokus pada kegiatan pembelajaran di kelas. Dari pembelajaran yang meyenangkan siswa seperti meberikan suport terhadap siswa pada saat belajar membeikan motivasi siswa agar dapat menigkatkan hasil belajar menjadi lebih baik lagi dari yag sebelumnya sehingga hasi pembelajaran dapat menjadi lebih optimal. Pemberikan motivasi seorang guru sangatlah penting untuk membangun keingianan belajar siswa pada dirinya oleh karena itu, guru harus memiliki kemampauan yang biak Agar bermanfaat. Di samping itu, pemberian tugas yang mengharuskan siswa untuk berkopetensi satu sama lain juga menjadikan metode untuk meningkatkan motivasi belajar siswa agar tercapai pada suatu tujuan. 
Terciptanya suasana belajar yang menyenangkan adalah faktor utama keberhasilan proses pembelajaran. Suasana belajar yang menyenangkan dan kondusif akan mendukung minat siswa untuk melaksanakan pembelajaran. Untuk mencapai Susana belajar yang menyenangkan tentu dibutuhkan kerja sama yang baik antara guru dengan siswa sebagai salah satu komponen pembelajaran. Untuk mempertahankan motivasi dalam diri siswa guru harus memiliki strategi yang bak dan kreatif.

Pada saat proses pembelajaran banyak sekali kendala yang diahadapi dalam memotivasi siswa. Dalam kegiatan belajar ada beberapa faktor yang mempengaruhi motivasi belajar siswa yaitu factor internal dan faktor eksternal. Factor internal yang mempengaruhi motivasi belajar siswa yaitu adanya sikap peserta didik, adanya usaha peserta didik dan adanya minat peserta didik. Sedangkan factor internal yang mempengaruhi motivasi belajar siswa yaitu lingkungan sekolah yang kondusif, lingkungan masyarakat dan lingkungan keluarga. Oleh karena itu dalam memotivasi belajar siswa pada masa pembelajaran daring kerja sama guru, orang tua dan masyarakat sangat dibutuhkan sehingga siswa bersemangat mengikuti pembelajaran daring.

Hasil Penelitan ini di latar belakangi keterkaitan dengan kaijan relevan yang terdahulu yaitu ke satu Ade tri ikhsaniyah, (2017) yang berjudul "motivasi siswa madrasah (studi kasus di MTS Negeri Pamalang). hasil dari penelitan ini dapat disimpulkan bahwa faktor yang mempengaruhi motivasi siswa sekolah di madrasah berdasarkan pengetahuan tentang madrasah, fasilitas sekolah lokasi, sekolah ilmu pengetahuan, serta biaya pendidikan. Sehingga terdapat persamaan yaitu motivasi siswa dan perbedaannya yaitu studi siswa.

Hasil penelitian kedua, Situmorang, (2016) dengan judul Hubungan antara potensi Kreatipitas dan Motivasi prestasi Mahasiswa Program Studi Bimbingan dan Konseling Hasil penelitian ini menunjukkan bahwa ada hubungan positif yang signifikan antara variable potensi kreativitas dengan motivasi berprestasi. 


\section{KESIMPULAN}

Berdasarkan hasil penemuan peneliti dilapangan peran guru dalam memotivasi siswa dalam pembelajaran daring maka dapat disimpulkan bahwa;

1. Peran seorang guru sangat penting karena dimulai dari tingkah laku guru yang dapat dijadikan dasar utama motivasi bagi siswa. Karena dengan kebiasaan baik, siswa akan mampu mengalami peningkata belajar. Bentukbentuk motivasi belajar yang diberikan kepada siswa seperti guru memberikan semangat kepada siswa melalui chat, pemberian tugas, pemberian pujian serta memiliki kerja sama yang baik antara guru dengan siswanya.

2. Kendala yang dialami siswa pada masa pembelajaran daring yaitu berbagai macam seperti kendala jaringan internet dan rendahnya aktivitas belajar siswa. Factor tersebut termasuk kedalam factor eksternal dan internal siswa.

\section{DAFTAR PUSTAKA}

Abdul, H. (2017). Guru Profesional. Al Falah, 275.

Ikhsniyah, T.A (2017). motivasi siswa madrasa (studi kasus di MTS Negeri pemalang), semarang : Fakulras ilmu tarbiya.

Arikunto, S. (2014). Prosedur Penelitian. Jakarta: 203.

Babuta, A. I., \& Rahmat, A. (2019). Pendidikan Kopetensi Pedagodik Guru Melalui Pelaksanaan Supervisi Klinis Dengan Teknik Kelompok. Manajemen Pendidikan Islam, 7.

Diana, S. (2017). Peran Orang Tua Dalam Memotivasi Belajar Siswa. Leaming Motivation, 41.

Djamarah, S. B. (2018). Psikologi Belajar. Jakarta: PT Rinerka Cipta.

Gunawan, I. (2013). Metode Penelitian Kualitatif Teori \& Praktik. Jakarta: PT Bumi Aksara.

Haerunisa, D., Haerunisa, B. M., \& Apsari, N. C. (2015). Pemenuhan Kebutuhan Dasar Anak Oleh Panti Sosial Asuhan Anak . Prosiding Penelitian, 27.

Hamdu , G., \& Agustina, L. (2011). Pengaruh Motivasi Belajar Siswa Terhadap Prestasi Belajar Ipa di Sekolah Dasar. Penelitian Pendidikan, 82.

Harlinda, S. (2016). Penyuluhan dan Pelatihan Pendidikan Tentang Pembuatan Kisi-Kisi Soal Untuk Guru di Yayasan Perguruan Republik Waalidain Semplak Bogor. Abdimas, 14. 
Ismail. (2015). Peningkat Kopetensi Pedagodik Guru Pai Dalam Pembelajaran. Mudarrisuna, 707.

Jahja, Y. (2011). Psikologi Perkembangan . Jakarta: Prenadamedia Group.

Jahja, Y. (2015). Psikologi Mama. Jakarta: PeenadaMedia Group.

Matondang, Z. (2018). Validitas Reabilitas Suatu Instrumen Penelitian. Tabularasa, 87.

Muhammad, A. (2018). Menjadi Guru Profesional. Jakarta: Perdamedia Group.

Mukh, S. (2015). Peran Orang Tua Dalam Bimbingan Konseling Siswa. Kependidikan, 2027.

Priharanta, W. (2015). Teori-Teori Motivasi. Adabiya, 5.

Purwanto, A. (2018). BAB II Kajian Pustaka Gastropoda. jurnal pendidikan, 84(5).

Rahmat, P. S. (2018). Psikologi Pendidikan. Jakarta Timur: Pt Bumi Aksara

Rumbewas, S. S., Laka, B. M., \& Meokbun, N. (2018). Peran Orang Tua Dalam Meningkatkan Motivasi Belajar Peserta Didik di SD Negeri Saribi. EdumatSains, 204.

Sihabudin, M. (2015). Peran Orang Tua Dalam Bimbingan Konseling Siswa. Kependidikan, 127.

Simarmarta, R. H. (2014). Upaya Peningkatan Motivasi Kerja Guru Sekolah. Administrasi Pendidikan, 657.

Situmorang, D. D. (2016). Hubungan anatar potensi kreativitas dan motivasi berperstasi mahasiswa program studi bimbingan dan konseling angakatan 2010 fkip unika atma jaya. Jurnal Bimbingan Konseling Indonesia, 1(1), 69.

Sofyana, L., \& Rozaq, A. (2019). Pembelajaran Daring Kombinasi Whatsapp Pada Kelas Karyawan Prodi Teknik Informatika Universitas PGRI Madiun. Janapati, 8(1), 81-86.

Sugiyono. (2013). Metode Penelitian Manajemen. Bandung: Alfabeta Cv.

Sugiyono. (2016). Metode Penelitian Pendidikan. Bandung: Alfabeta Cv.

Suwardi, D. R. (2012). Faktor-faktor Yang Mempengaruhi Hasil Belajar Siswa Kopetensi Ayat Jurnal Penyesuaian Mata Pelajaran Akutansi Klas XI IPS di SMA Negeri 1 Bangkek Kudus. Economic Education Analysis Jurnal, 6.

Widayat, p. (2015). teori teori motivasi. Adabiya, 2.

Yusuf, S., \& Sugandi, N. M. (2018). Perkembangan Peserta Didik. Depok: Pt RajaGrafindoPersada. 